\title{
The role of mobile communication devices in the spread of infections within a clinical setting
}

\author{
Tricia Corrin*, Joanne Lin*, Catherine MacNaughton*, Sarah Mahato* and Aarabhi Rajendiran* \\ *Master of Public Health Program, University of Guelph, Guelph, ON, Canada. (All authors contributed equally to the paper.)
}

\begin{abstract}
Mobile communication devices (MCDs) are routinely used in clinical settings. Bacterial contamination of MCDs is a growing concern as they can serve as a potential reservoir for infectious diseases. Recent studies have found that between $9 \%$ and $15 \%$ of MCDs carry pathogenic bacteria. To reduce contamination, recommendations are to practice good hand hygiene, restrict MCDs in high-risk areas, and sanitize MCDs using 70\% isopropyl alcohol.
\end{abstract}

Key words: infectious disease, public health, cell phone, hospital-acquired infection, mobile communication device

\section{Introduction}

Ubiquitous is a term readily applied to microbes and mobile communication devices (MCDs) alike. In a clinical setting however, this combination can become a hazard. MCDs include a wide range of electronics such as cell phones, tablets, personal digital assistants (PDAs), and pagers. Ascertaining the number and types of microbes found on MCDs, their origins and destinations, as well as determining effective reduction protocols are the best methods for mitigating this potential hazard. In this review, we examine the risk associated with MCDs as a reservoir for microbes, in particular, those that cause nosocomial or hospital-acquired infections (HAIs). Furthermore, we examine the bacterial load on MCDs including its prevalence, types of bacteria found (pathogenic and non-pathogenic), effects of sanitation, and recommendations going forward.

On dry surfaces, most gram-positive bacteria, including Methicillin-resistant Staphylococcus aureus (MRSA) and Vancomycin-resistant enterococci (VRE) have been shown to survive for months (Kramer et al., 2006). Some of the papers in this review included a questionnaire regarding phone sanitation. Rates were low, such as in Singh et al. (2002), where 88\% of respondents stated they had never cleaned their phone. These two findings reflect the potential of MCDs as fomites and dangers to human health in a clinical setting.

\section{Methods}

Literature for this review was obtained from the following databases and search engines: Google Scholar, the University of Guelph Libraries (PRIMO), University of Ottawa Libraries (SCOPUS),

Corresponding author: Tricia Corrin (email: pcorrin@uoguelph.ca) and the National Center for Biotechnology Information (NCBI). A few sources were also found as a result of being referenced by other papers that were examined. Search terms used to extract literature from the aforementioned websites were a combination of the following: "mobile phone bacteria", "cell phone bacteria", "infectious mobile", "antibiotic resistance phone", "MRSA phone", "hospital staff cell phone", and "fecal bacteria phones". Developing countries such as Pakistan, India, and countries in the middleEast were excluded from this literature search as conditions of the physical and social environment may differ too greatly for results to be extrapolated to North American contexts. Prevalence and type of bacteria, clinical hygiene standards and practices, and mobile communication device usage patterns all may be distinct in developing countries.

\section{Risk assessment}

\section{Mobile communication devices}

MCDs have become instrumental in everyday life. According to a 2012 study, $75 \%$ of Canadians owned a mobile phone (Canadian Wireless Telecommunication Association, 2012). Smartphones made up $48 \%$ of those mobile phones (Canadian Wireless Telecommunication Association, 2012). It is estimated that by $2018,93 \%$ of mobile phones in North America will be smartphones (Cisco Systems Inc, 2014).

In a clinical setting, healthcare workers (HCWs) use MCDs on a day-to-day basis for work and social purposes. Studies indicate that $87 \%-88 \%$ of $\mathrm{HCW}$ use their MCD at the workplace (Koehler et al., 2013; Mark et al., 2014). These devices are used primarily to optimize patient care and client communications (Julian et al., 2012). Specifically, MCDs are used to access laboratory results, conduct Internet research, and seek consultation amongst colleagues (Mark et al., 2014). 
Reliance on mobile technology is increasing. As of 2013, there were approximately 20,000 medical apps available for download (Aungst, 2013). Some common apps include drug guides, medical calculators, coding and billing apps, and pregnancy wheels (Franco and Tirrell, 2011). Improvements to health such as better patient control of diabetes (Ferrer-Roca et al., 2004) and the increase in vaccination rates of travelers (Vilella et al., 2004) have been facilitated through the use of mobile innovations.

Patients and visitors also use their MCDs to communicate with relatives and manage their business from the hospital (Tekerekoğlu et al., 2011). It has been demonstrated that inpatient experience can be enhanced through the use of MCDs (Brady et al., 2011). In addition, a study indicates that $92.6 \%$ of patients support the use of MCDs in hospitals (Brady et al., 2011).

\section{Hospital-acquired infections}

HAIs fundamentally undermine the goal of any healthcare facility. Infections of this nature are acquired due to hospital admittance; a patient admitted for other reasons and not infected at the time of admittance then becomes ill because of an infection acquired during their hospital stay (Ducel et al., 2002). The yearly toll of HAIs in Canadian hospitals is close to a quarter million occurrences and over 8,000 deaths (Zoutman et al., 2003). Patients at-risk are those least able to bear the burden such as the elderly, the immunocompromised, and those already burdened with another disease or disability (Zoutman et al., 2003). The costs of HAIs include longer hospital stays, greater healthcare costs, additional bodily and mental stress on the patient, possible long-term disability, hospital re-admittance, imbalance of hospital resources through reallocation to potentially preventable illness, and for some death (Ducel et al., 2002; Canadian Institute for Health Information, 2008).

Converging in hospitals are multiple factors that allow for the development of HAIs. Patients are more susceptible to infection because of their physical condition (e.g., age, immune status, chronic disease, etc.) or due to medical procedures (e.g., immunosuppression, irradiation, catheterization, intubation, etc.) (Ducel et al., 2002). Among these patients are those admitted for an infection; these infected and susceptible groups are then mixed together through the shared hospital environment (Ducel et al., 2002). Further compounding the issue is antibiotic resistance in some of the microbes that cause HAIs (Ducel et al., 2002).

Three of the HAIs monitored by the Canadian Nosocomial Infection Surveillance Program are MRSA infections, VRE infections, and Clostridium difficile infections (Public Health Agency of Canada, 2013). These three are notable because they can be spread via skin-to-skin contact or contact with contaminated surfaces (Ducel et al., 2002). Given the level of interaction required to administer care in a hospital (Public Health Agency of Canada, 2013), these routes of transmission are of great importance. As an example of the continued and growing issue of HAIs note that MRSA infections in Canada have increased 1000-fold in less than 15 years (Public Health Agency of Canada, 2013).

\section{Discussion}

A summary of the findings can be found in Table 1. Although the majority of the studies we reviewed were conducted in a hospital or clinical setting, two studies tested MCDs for harmful bacteria outside of this environment. Blankinship et al. (2013) looked for antibiotic resistant bacteria on keyboards and cell phones of faculty, staff, and students at the University of Alabama, whereas Meadow et al. (2014) cultured bacteria off of touchscreen PDAs in a workshop. Blankinship et al. (2013) reported that antibiotic resistance was low and Meadow et al. (2014) reported that typical skin organisms are more likely found on PDAs than pathogenic organisms. MCDs are most likely not a source of infection for people outside of a clinical setting.

Studies that were conducted in a clinical setting found a range of bacteria on MCDs. The majority of MCDs were sampled from HCWs, such as physicians and nurses, with the exception of one study that sampled patient phones (Beckstrom et al., 2013). The most common types of bacteria found on MCDs were bacterial skin flora. These non-pathogenic bacteria include Coagulase-negative Staphylococcus spp., Micrococcus spp., Diphtheroid spp., and Bacillus. For most studies, the greatest concern was to report pathogens such as MRSA and Methicillinsensitive Staphylococcus aureus. Other pathogenic bacteria that were found on MCDs were Acinetobacter spp., Pseudomonas spp., and VRE. These strains of bacteria can be a source of infection for both HCWs and their patients.

A study conducted by Braddy and Blair (2005) found zero traces of pathogenic bacteria. In contrast, many other studies found that approximately $9 \%-15 \%$ of MCDs were associated with bacteria that could cause infections (Brady et al., 2006, 2007, 2011; Karabay et al., 2007). MRSA levels varied from $0.1 \%$ to $12 \%$, whereas one study in Turkey reported that MRSA was found on 52\% of MCDs (Singh et al., 2002; Hassoun et al., 2004; Goldblatt et al., 2007; Ulger et al., 2009; Julian et al., 2012; Ustun and Cihangiroglu, 2012; Beckstrom et al., 2013; Pal et al., 2013).

Studies have reported that between $85 \%$ and $93 \%$ of HCWs never clean their MCDs (Singh et al., 2002; Hassoun et al., 2004; Brady et al., 2007). Furthermore, Mark et al. (2014) found that $45 \%$ of medical professionals never wash their hands after phone usage. Since a significant number of MCDs carry pathogenic bacteria, there is a need to determine the risk of transmission from MDCs to both HCWs and patients.

\section{Recommendations}

There are currently no recommendations regarding safe MCDuse in clinical settings in the countries in which the studies were conducted (Canada, the United States, Austria, Turkey, and the United Kingdom). However, the studies reviewed did have recommendations on how to control HAIs infections as a result of MCDs. The strategy that was recommended by almost all authors and that was also deemed as most effective in reducing the potential of MCD-contamination was strict adherence with hand hygiene (Singh et al., 2002; Braddy and Blair, 2005; Goldblatt et al., 2007; Ulger et al., 2009; Brady et al., 2011; 
Table 1. Summary of papers

\begin{tabular}{|c|c|c|}
\hline Authors & Sample size and trial type & Main findings \\
\hline Basol et al., 2014 & $\begin{array}{l}\text { Chicago, USA } \\
\text { - } n=66 \text { shared mobile phones routinely used } \\
\text { by clinical Registered Nurses (in } 11 \text { acute care } \\
\text { units and critical care units) } \\
\text { - Randomized control trial }\end{array}$ & $\begin{array}{l}\text { - No pathogenic bacteria detected on mobile } \\
\text { phones before or after using wipes } \\
\text { - Normal skin flora (Coagulase-negative } \\
\text { Staphylococcus spp., Micrococcus spp., } \\
\text { Diphtheroid spp., and Bacillus spp.) was reduced } \\
\text { from } 64 \% \text { to } 12 \% \text { with isopropyl alcohol wipes } \\
\text { and } 64 \% \text { to } 15 \% \text { with ethyl alcohol wipes, as a } \\
\text { result mobile phones weren't a source of } \\
\text { healthcare-associated infections } \\
\text { - Cleaning of mobile phones using alcohol wipes } \\
\text { effectively eliminates bacteria }\end{array}$ \\
\hline $\begin{array}{l}\text { Blankinship et al., } \\
2013\end{array}$ & $\begin{array}{l}\text { Alabama, USA } \\
-n=20 \text { mobile phones } \\
\text { - } \quad \text { Cross-sectional study }\end{array}$ & $\begin{array}{l}\text { - } 38 \text { bacterial isolates identified, } \\
\text { - Some isolates were pathogenic, whereas other } \\
\text { isolates were multidrug resistant, which could } \\
\text { lead to HAI } \\
\text { - Antibiotic resistance predicted to increase with } \\
\text { the continued overuse/misuse of antibiotics }\end{array}$ \\
\hline $\begin{array}{l}\text { Beckstrom et al., } \\
2013\end{array}$ & $\begin{array}{l}\text { Washington, USA } \\
\text { - } n=50 \text { mobile phones and hands } \\
\text { - } \text { Questionnaire } \\
\text { - Cross-sectional study }\end{array}$ & $\begin{array}{l}\text { - Before applying antimicrobial gel, } 96 \% \text { of hands } \\
\text { had bacteria ( } 2 \text { had Acinetobacter spp. and } 1 \text { had } \\
\text { MRSA) before applying antimicrobial gel and } \\
\text { only } 26 \% \text { of hands had no bacterial growth after } \\
\text { using antimicrobial gel } \\
\text { - Antimicrobial gel is not an appropriate way to } \\
\text { eliminate bacteria transmitted from cell phone } \\
\text { to hand }\end{array}$ \\
\hline $\begin{array}{l}\text { Braddy and Blair, } \\
2005\end{array}$ & $\begin{array}{l}\text { Arizona, USA } \\
\text { - } n=82 \text { PDAs } \\
\text { - Healthcare workers in hospital and clinics } \\
\text { - } \text { Questionnaire } \\
\text { - } \text { Randomized trial }\end{array}$ & $\begin{array}{l}\text { - } 40 \% \text { of the PDAs showed organism growth of } \\
\text { which coagulase-negative Staphylococcus was } \\
\text { the most common organism found } \\
\text { The specific type of healthcare job, hand- } \\
\text { washing technique and presence/type of PDA } \\
\text { cover had no correlation with the presence of } \\
\text { bacterial/fungal growth } \\
\text { - PDAs often contain organisms found on skin, } \\
\text { and less often are colonized by organisms that } \\
\text { cause disease }\end{array}$ \\
\hline Brady et al., 2011 & $\begin{array}{l}\text { Edinburgh, UK } \\
\text { - } n=102 \text { mobile phones, } \\
\text { males and females } 16 \text { years of age or older } \\
\text { - Inpatients on surgical/urological wards of } \\
\text { hospital } \\
\text { - Questionnaire } \\
\text { - Cross-sectional surveillance study }\end{array}$ & $\begin{array}{l}\text { - } 84.3 \% \text { of mobile phones tested were contaminated } \\
\text { with bacteria, of which } 11.8 \% \text { contained } \\
\text { nosocomial infection-causing bacteria } \\
\text { - Of those with pathogenic bacteria species, no } \\
\text { association was found between gender or age } \\
\text { There is an association between MRSA } \\
\text { contamination in the nasal cavity and finding } \\
\text { MRSA colonies on mobile phones }\end{array}$ \\
\hline Brady et al., 2006 & $\begin{array}{l}\text { Northern Ireland, UK } \\
\text { - } n=105 \\
\text { - doctors, nursing staff } \\
\text { - Questionnaire } \\
\text { - Cross-sectional study }\end{array}$ & $\begin{array}{l}\text { - } 96.2 \% \text { of phones showed evidence of bacterial } \\
\text { contamination } \\
\text { - Coagulase-negative staphylococcus was isolated } \\
\text { most often }(93 \%) \\
\text { - } 15 \% \text { of phones had bacteria known to cause } \\
\text { nosocomial infections } \\
\text { No statistically significant association between } \\
\text { finding bacterial growth and doctor/nurse, } \\
\text { medical speciality, type of phone (e.g., flip-top, } \\
\text { clam shell, or sliding), daily presence of phone }\end{array}$ \\
\hline
\end{tabular}


Table 1 (continued).

\begin{tabular}{|c|c|c|}
\hline Authors & Sample size and trial type & Main findings \\
\hline Brady et al., 2007 & $\begin{array}{l}\text { Edinburgh, Scotland } \\
\text { - } n=78 \text { MCDs (mobile phones, pagers, } \\
\text { PDAs) } \\
\text { - } \text { surgeons, anaesthetists, and medical students } \\
\text { - } \text { Questionnaire } \\
\text { Cross-sectional study }\end{array}$ & $\begin{array}{l}\text { - } 84.8 \% \text { of phones, } 96.3 \% \text { of pagers, } \\
80 \% \text { of PDAs were never cleaned prior } \\
\text { to study } \\
89.7 \% \text { MCDs were found with bacteria, } \\
11.5 \% \text { of which had bacteria that could } \\
\text { cause nosocomial infection ( } 3 \text { MCDs with } \\
\text { MSSA) } \\
\text { - No attention placed on mobile phones in } \\
\text { clinical practice o reduce HAI }\end{array}$ \\
\hline Goldblatt et al., 2007 & $\begin{array}{l}\text { New York, NY } \\
\text { Haifa, Israel } \\
-\quad n=400 \text { mobile phones } \\
\text { - HCWs, and others not employed in the } \\
\text { hospital } \\
\text { - Questionnaire } \\
\text { - Cohort study }\end{array}$ & $\begin{array}{l}\text { - } 50 \% \text { of physicians and nurses carried } \\
\text { MCDs and used them while attending } \\
\text { to patients, regardless of signs banning } \\
\text { cell phone use in hospitals } \\
\text { - } 20 \% \text { mobile phones harboured potentially } \\
\text { pathogenic microorganisms } \\
\text { - MRSA }(10.3 \%) \text { was most common microbial in } \\
\text { New York } \\
\text { - Mobile phones that did not enter the hospital } \\
\text { had no bacterial growth }\end{array}$ \\
\hline Hassoun et al., 2004 & $\begin{array}{l}\text { New York, USA } \\
\bullet \quad n=75 \text { PDAs of HCWs } \\
\text { - } \quad \text { prospective } \\
\text { - } \quad \text { Cross-sectional study }\end{array}$ & $\begin{array}{l}\text { - } 93 \% \text { of HCWs never cleaned their PDAs } \\
\text { - } 96 \% \text { of samples were culture positive before } \\
\text { cleaning with alcohol swab } \\
\text { - } 85 \% \text { had coagulase-negative Staphylococcus } \\
\text { prior to cleaning, } 11 \% \text { of PDAs had } \\
\text { S. aureus, } 75 \% \text { of which were MRSA prior to } \\
\text { cleaning } \\
\text { - } 75 \% \text { became culture negative after cleaning } \\
\text { with an alcohol swab, thus it helped } \\
\text { significantly reduce microbial contamination } \\
\text { on PDAs } \\
\text { - No direct evidence that bacteria on PDA will } \\
\text { infect patients }\end{array}$ \\
\hline Jeske et al., 2007 & $\begin{array}{l}\text { Austria } \\
\text { - } \quad n=40 \text { anaesthetists } \\
\text { - } \quad \text { Pilot study }\end{array}$ & $\begin{array}{l}\text { - After use of in-hospital mobile phones, } \\
\text { bacterial contamination was found on } \\
95 \% \text { of anaesthetists' hands and } 10 \% \text { of } \\
\text { anaesthetists' hands showed pathogenic } \\
\text { bacteria } \\
\text { - Compared with fixed phones in the hospital, } \\
83 \% \text { of anaesthetists showed bacterial } \\
\text { contamination }(10 \% \text { of which showed } \\
\text { pathogenic bacteria) } \\
\text { - Use of mobile phones may have more } \\
\text { serious hygiene issues and carry greater } \\
\text { risk of unperceived contamination and } \\
\text { infection compared with fixed } \\
\text { phones }\end{array}$ \\
\hline Julian et al., 2012 & $\begin{array}{l}\text { Ontario, Canada } \\
\text { - } n=123 \\
\text { - Mobile phones, personal mobile phones, } \\
\text { hospital-issued } \\
\text { - Cross-sectional study }\end{array}$ & $\begin{array}{l}\text { - Methicillin-resistant staphylococci was isolated } \\
\text { from } 2.4 \% \text { of mobile phones } \\
\text { - } 21.9 \% \text { of personnel had cleaned their device } \\
\text { within the past month } \\
\text { - No difference in prevalence of contamination } \\
\text { overall between personal and hospital-issued } \\
\text { mobile phones }\end{array}$ \\
\hline
\end{tabular}


Table 1 (continued).

\begin{tabular}{|c|c|c|}
\hline Authors & Sample size and trial type & Main findings \\
\hline Karabay et al., 2007 & $\begin{array}{l}\text { Bolu, Turkey } \\
\text { - } \quad n=122 \text { mobile phones } \\
\text { - Cross-sectional study }\end{array}$ & $\begin{array}{l}\text { - } 91 \% \text { of mobile phones tested positive for bacteria } \\
\text { - Bacteria associated with hospital infections was } \\
\text { found on } 9 \% \text { of mobile phones (4 phones with } \\
\text { Escherichia coli, } 2 \text { phones showing Enterococcus } \\
\text { feacalis, } 2 \text { Pseudomonas aeruginosa samples, } 1 \\
\text { Pseudomonas fluorescensis, } 1 \text { phone with } \\
\text { Klebsiella pneumoniae) } \\
\text { - No MRSA or VRE }\end{array}$ \\
\hline Meadow et al., 2014 & $\begin{array}{l}\text { New Jersey, USA } \\
\text { - } n=17 \text { MCDs } \\
\text { - } \quad \text { Males and females } \\
\text { - } \quad \text { Cross-sectional study }\end{array}$ & $\begin{array}{l}\text { - } 22 \% \text { of the bacteria found on a PDA is found } \\
\text { on the owners hand, compared with } 17 \% \\
\text { shared with another person's phone } \\
\text { - As a group, the bacterial community on men's } \\
\text { phones were significantly different from their } \\
\text { fingers, whereas women's were not } \\
\text { - } 82 \% \text { of OTUs were shared between index } \\
\text { fingers and phone, whereas } 96 \% \text { of OTUs were } \\
\text { shared between index fingers and thumbs }\end{array}$ \\
\hline Mark et al., 2014 & $\begin{array}{l}\text { Belfast, UK } \\
\text { - } n=50 \text { mobile phone } \\
\text { - } n=150 \mathrm{HCWs} \\
\text { - Males and females } \\
\text { - Medical practitioners, nursing staff, auxiliary } \\
\text { medical professionals, secretarial staff, } \\
\text { andstudents } \\
\text { - } \text { Questionnaire } \\
\text { Cross-sectional study }\end{array}$ & $\begin{array}{l}\text { - } 60 \% \text { of phones had a contaminant isolated (the } \\
\text { majority of positive isolates was } \\
\text { staphylococcus) } \\
\text { - No drug-resistant strains of pathogenic } \\
\text { bacteria were identified } \\
\text { - } 88 \% \text { of HCWs use their mobile phone within the } \\
\text { workplace, } 55 \% \text { use it for clinical use (on-call) } \\
\text { - With proper hand hygiene it is safe to use } \\
\text { touchscreen mobile phones in a clinical } \\
\text { environment }\end{array}$ \\
\hline Namias et al., 2000 & $\begin{array}{l}\text { Florida, USA } \\
-\quad n=36 \text { pagers } \\
\text { - Physicians, residents, and respiratory } \\
\text { therapists } \\
\text { - Cross-sectional study }\end{array}$ & $\begin{array}{l}\text { - Study excluded microorganisms found on skin } \\
\text { or in the environment } \\
\text { - } 47 \% \text { of pagers were contaminated with } \\
\text { microbial pathogens } \\
\text { - HCW occupation and level of exposure in the } \\
\text { intensive care unit have no correlation to the } \\
\text { likelihood of contamination of the pager }\end{array}$ \\
\hline Pal et al., 2013 & $\begin{array}{l}\text { London, UK } \\
\text { - } n=71 \text { mobile phones ( keypad, touchscreen, } \\
\text { unsuitable for analysis) } \\
\text { - Mobile phones were exclusively on-call } \\
\text { hospital phones } \\
\text { - Phones came from medicine, surgery, and } \\
\text { anaesthetics departments } \\
\text { - Random sampling }\end{array}$ & $\begin{array}{l}\text { - } 13 \% \text { cell phones contained either MRSA or } \\
\text { VRE } \\
\text { - } 24 \% \text { keypad phones grew either MRSA or } \\
\text { VRE compared with one touch screen phone } \\
\text { ( } 3 \% \text { of the total } 9 \text { phones contaminated } \\
\text { Keypad phones are more likely to host } \\
\text { pathogenic bacteria and are more likely to } \\
\text { harbour drug-resistant bacteria } \\
\text { - Only criteria associated with a higher number } \\
\text { of bacteria recovered was whether the phone } \\
\text { had a keypad or a touchscreen (job or } \\
\text { department of owner had no bearing) }\end{array}$ \\
\hline $\begin{array}{l}\text { Tekerekoğlu et al., } \\
2011\end{array}$ & $\begin{array}{l}\text { Malatya, Turkey } \\
\text { - } n=200 \text { mobile phones } \\
\text { - Patients, patients' companions, visitors, } \\
\text { HCWs } \\
\text { - Cross-sectional study }\end{array}$ & $\begin{array}{l}\text { - Bacterial growth was found more often on } \\
\text { patients' mobile phones }(90.1 \%) \text { in comparison } \\
\text { with HCW's mobiles phones }(85.6 \%) \\
\text { - Multidrug-resistant pathogens were found on } \\
\text { the mobile phones of patients but not on the } \\
\text { mobile phones of HCWs }\end{array}$ \\
\hline
\end{tabular}


Table 1 (continued).

\begin{tabular}{|c|c|c|}
\hline Authors & Sample size and trial type & Main findings \\
\hline Singh et al., 2002 & $\begin{array}{l}\text { Ohio, USA } \\
-\quad n=100 \text { pagers } \\
\text { - HCWs (house staff, attending physicians, } \\
\text { registered nurses, respiratory therapists, and } \\
\text { medical students) } \\
\text { - } \text { Questionnaire } \\
\text { Prospective cross-sectional study }\end{array}$ & $\begin{array}{l}\text { - } 88 \% \text { of respondents reported never cleaning } \\
\text { their pager } \\
\text { - Microorganisms were isolated from all pagers: } \\
21 \% \text { of which contained S. aureus, } 14 \% \text { of } \\
\text { which were MRSA } \\
\text { - Emergency, intensive care, and respiratory } \\
\text { units had significantly higher microbial rates } \\
\text { - Cleaning with } 70 \% \text { isopropyl alcohol reduced } \\
\text { the total colony count by an average of } 94 \% \\
\text { - Hand hygiene policy and increased adherence is } \\
\text { vital }\end{array}$ \\
\hline Ulger et al., 2009 & $\begin{array}{l}\text { Samsun, Turkey } \\
\text { - } n=200 \text { mobile phones and hands } \\
\text { - Cross-sectional study }\end{array}$ & $\begin{array}{l}\text { - } 94 \% \text { of mobile phones were contaminated with } \\
\text { bacteria } \\
\text { - } 52 \% \text { of mobile phones and } 37.7 \% \text { of hands } \\
\text { were contaminated with MRSA } \\
\text { - There was cross-contamination of bacteria } \\
\text { between dominant hands and } 33.33 \% \text { of mobile } \\
\text { phones }\end{array}$ \\
\hline $\begin{array}{l}\text { Ustun and } \\
\text { Cihangiroglu, } 2012\end{array}$ & $\begin{array}{l}\text { Elazig, Turkey } \\
\text { - } n=183 \text { mobile phones } \\
\text { - Nurses, laboratory workers, healthcare staff } \\
\text { - Cross- sectional study, secondary referral } \\
\text { - hospital } \\
\text { - Second division was by ICU/non-ICU }\end{array}$ & $\begin{array}{l}\text { - } 97.8 \% \text { of culture-positive specimens isolated } \\
\text { from mobile phones } \\
\text { - } 9.5 \% \text { of phones had MRSA, } 11.2 \% \text { had ESBL- } \\
\text { producing Escherichia coli, which can cause } \\
\text { nosocomial infections } \\
\text { - } \text { Recovery of MRSA and ESBL-producing } \\
\text { E.coli was not statistically linked to a HCW } \\
\text { group } \\
\text { - } 24.6 \% \text { of specimens were isolated from mobile } \\
\text { phones of ICU workers } \\
\text { - Isolation of ESBL-producing E.coli was } \\
\text { statistically higher in ICU workers compared to } \\
\text { non-ICU workers }\end{array}$ \\
\hline White et al., 2012 & $\begin{array}{l}\text { West Yorkshire, UK } \\
\text { - } n=16 \text { smartphones } \\
\text { - Males and females } \\
\text { - Longitudinal sampling of mobile devices } \\
\text { - } \text { Operating department practitioner students }\end{array}$ & $\begin{array}{l}\text { - All devices had microbial contamination and } \\
86 \% \text { had polymicrobial contamination } \\
\text { - Staphylococcus was the most common } \\
\text { organism found } \\
\text { - Mobile phones are contaminated with a lot of } \\
\text { transient and potentially transferrable bacteria }\end{array}$ \\
\hline
\end{tabular}

Note: HAI, hospital-acquired infections; MRSA, Methicillin-resistant Staphylococcus aureus; PDA, personal digital assistant; MCD, mobile communication device; MSSA, Methicillinsensitive Staphylococcus aureus; HCW, healthcare worker; VRE, Vancomycin-resistant enterococci; OTU, operational taxonomic units; ICU, intensive care unit; ESBL, extended-spectrum beta-lactamase, enzymes that confer resistance to penicillin.

Julian et al., 2012; Ustun and Cihangiroglu, 2012; White et al., 2012; Beckstrom et al., 2013; Pal et al., 2013; Basol et al., 2014; Mark et al., 2014). Other recommendations included: specific infection control measures, training of HCWs and patients and their families regarding strict control procedures, and methods to disinfect MCDs.

Beckstrom et al. (2013) noted that bacteria transmitted from a cell phone to hands may not be eliminated by anti-microbial gel, and therefore they recommended prevention through hand hygiene and cell phone cleaning guidelines. They also noted that the safest approach to minimize the risk of bacterial transmission from cell phones is to generate a "no tolerance" policy, which would prohibit their use at the bedside. However, Mark et al. (2014) found $75 \%$ of HCWs sampled felt banning mobile phones would "not be a practical or realistic solution to reduce infection." Therefore, a more realistic and enforceable approach would be to reduce the bacterial load on hands by educating HCWs and the families of patients on regular cleaning of MCDs and hand hygiene as well as limiting sharing and usage of MCDs around patients.

Ulger et al. (2009) recommended limiting mobile phone usage in the settings that are in close proximity with patients such as 
operating rooms and intensive care units because of the high risk for spreading infections. Another recommendation was routine decontamination of mobile phones with alcohol wipes or regular cleaning agents to reduce cross-infection. White et al. (2012) noted that sharing phones could directly facilitate the spread of pathogenic bacteria both in and out of the hospital. In concordance with Ulger et al. (2009), they recommend that strict regulations should be in place to limit mobile phone usage in hospital settings to reduce the spread to both internal and external environments. Basol et al. (2014) recommended using either 70\% isopropyl alcohol wipes or ethyl alcohol wipes; both were deemed effective in eliminating bacteria on MCDs. Two studies found that due to the uneven surface of a keypad, such devices were able to harbour more bacteria than the smooth surface of touchscreen phones (Pal et al., 2013; Mark et al., 2014); as a result, they recommended investing in touchscreen phones for clinical use as cost-effective in reducing infection risk.

Despite the weight of evidence regarding bacterial transmission and MCDs in clinical settings, there has yet to be a knowledge translation of this evidence into guidelines that can be used by all stakeholders. After reviewing the literature regarding MCD use in clinical settings and HAIs, the studies overwhelmingly show that MCDs are a potential source for bacterial transmission, and therefore regulations that specifically mandate good hand hygiene and limit the use of MCDs must be in place to control pathogenic and infectious spread in clinical settings.

\section{Limitations}

There are limitations to the application of the findings in this review in a Canadian setting. Firstly, Julian et al. (2012) published the only paper that using Canadian data. An overwhelming number of studies were conducted in the Middle East and South Asia; however, to maximize generalizability to Canada only articles published in the United States, United Kingdom, Austria, and Turkey were used. As a result a small number of studies were reviewed, which limits the characterization of potential risk factors of MCDs with respect to HAIs. Lastly, this review looked at primary research articles that had relatively small sample sizes and no controls. This could be why causal relationships were not identified between MCD use and HAIs.

\section{Conclusion}

MCDs have provided an accurate and efficient means of communication in health care and as a result have improved patient quality-of-care (Pal et al., 2013). There is evidence of bacterial presence, including pathogenic bacteria, on MCDs used in clinical settings and this presents a risk of HAIs. Hand hygiene was concluded to be the most effective infection control method in reducing phone contamination potential and risk of HAIs. Other recommendations include disinfection using $70 \%$ isopropyl alcohol or ethyl alcohol wipes, mandating strict disinfection control guidelines, the use of touch-screen devices over keypad devices, limiting MCD use, and educating HCWs and patients and their families regarding MCD disinfection methods and hand hygiene. Further research should be conducted on MCDs in the clinical setting and the evaluation of disinfection methods to determine the efficacy of sampling techniques and cleaning methods (White et al., 2012). A key area for further investigation is determining the true risk of HAIs as a result of MCD use in clinical settings (White et al., 2012). It is only in carrying out such work that policy makers can develop a "robust evidence-based infection control policy" (White et al., 2012) regarding MCDs in clinical settings.

\section{References}

Aungst, T. 2013. Available at http://www.imedicalapps.com/2013/ 07/apple-android-medical-app/.

Basol, R., Beckel, J., and Gilsdorf-Gracie, J. 2014. Bacteria on shared mobile phones can lead to infections. Nurs. Crit. Care. 9(4): 5-7. doi: 10.1097/01.CCN.0000451027.49482.59.

Beckstrom, A. C., Cleman, P. E., Cassis-Ghavami, F. L., and Kamitsuka, M. D. 2013. Surveillance study of bacterial contamination of the parent's cell phone in the NICU and the effectiveness of an anti-microbial gel in reducing transmission to the hands. J. Perinatol. 33(12): 960-963. doi: 10.1038/jp.2013.108.

Blankinship, L. A., Cotton, B. L., and Gaston, J. L. 2013. Survey of antibiotic resistance in cell phone and computer keyboard isolated bacteria. Bios. 83(3): 165-172. doi: 10.1893/0005-3155-84.3.165.

Braddy, C. M., and Blair, J. E. 2005. Colonization of personal digital assistants used in a health care setting. Am. J. Infect. Control. 33(4): 230-232. doi: 10.1016/j.ajic.2005.03.003.

Brady, R. R., Fraser, S. F., Dunlop, M. G., Paterson-Brown, S., and Gibb, A. P. 2007. Bacterial contamination of mobile communication devices in the operative environment. J. Hosp. Infect. 66(4): 397-398. doi: 10.1016/j.jhin.2007.04.015.

Brady, R. R., Hunt, A., Visvanathan, A., Rodrigues, A., Graham, C., Rae, C., et al. 2011. Mobile phone technology and hospitalized patients: A cross-sectional surveillance study of bacterial colonization, and patient opinions and behaviours. Clin. Microbiol. Infect. 17(6): 830-835. doi: 10.1111/j.1469-0691.2011.03493.x.

Brady, R. R., Wasson, A., Stirling, I., McAllister, C., and Damani, N. N. 2006. Is your phone bugged? The incidence of bacteria known to cause nosocomial infection on healthcare workers' mobile phones. J. Hosp. Infect. 62(1): 123-125. doi: 10.1016/j.jhin.2005.05.005.

Canadian Institute for Health Information. 2008. Available at https:// secure.cihi.ca/free_products/PSAF_AIB_2008_10_23_e.pdf.

Canadian Wireless Telecommunication Association. 2012. Available at http://cwta.ca/wordpress/wp-content/uploads/2011/08/CWTA2012ConsumerAttitudes.pdf.

Cisco Systems Inc. 2014. Available at http://www.cisco.com/c/en/us/ solutions/collateral/service-provider/visual-networking-index-vni/ white_paper_c11-520862.html.

Ducel, G., Fabry, J., and Nicolle, L. 2002. Prevention of hospital acquired infections: A practical guide, Edition 2. World Health Organization. Available at: http://apps.who.int/medicinedocs/ documents/s16355e/s16355e.pdf.

Ferrer-Roca, O., Cárdenas, A., Diaz-Cardama, A., and Pulido, P. 2004. Mobile phone text messaging in the management of diabetes. J. Telemed. Telecare. 10(5): 282-285. doi: 10.1258/135763304 2026341.

Franco, O., and Tirrell, T. 2011. Smartphone app use among medical providers in ACGME training programs. J. Med. Syst. 36(5): 3135-3139. doi: 10.1007/s10916-011-9798-7. 
Goldblatt, J. G., Krief, I., Klonsky, T., Haller, D., Milloul, V., Sixsmith, D. M., et al. 2007. Use of cellular telephones and transmission of pathogens by medical staff in New York and Israel. Infect. Control. Hosp. Epidemiol. 28(4): 500-503. doi: 10.1086/513446.

Hassoun, A., Vellozzi, E. M., and Smith, M. A. 2004. Colonization of personal digital assistants carried by healthcare professionals. Infect. Control. Hosp. Epidemiol. 25(11): 1000-1001. doi: $10.1086 / 502334$.

Jeske, H. C., Tiefenthaler, W., Hohlrieder, M., Hinterberger, G., and Benzer, A. 2007. Bacterial contamination of anaesthetists' hands by personal. Anaesthesia. 62(9): 904-906. doi: 10.1111/j.13652044.2007.05172.x.

Julian, T., Singh, A., Rousseau, J., and Weese, J. S. 2012. Methicillinresistant staphylococcal contamination of cellular phones of personnel in a veterinary teaching hospital. BMC. Res. Notes. 5: 193.

Karabay, O., Koçoglu, E., and Tahtaci, M. 2007. The role of mobile phones in the spread of bacteria associated with nosocomial infections. J. Infect. Dev. Ctries. 1(1): 72-73.

Koehler, N., Vujovic, O., and McMenamin, C. 2013. Healthcare professionals' use of mobile phones and the internet in clinical practice. J. Mob. Technol. Med. 2(1): 3-13. doi: 10.7309/jmtm.76.

Kramer, A., Schwebke, I., and Kampf, G. 2006. How long do nosocomial pathogens persist on inanimate surfaces? A systematic review. BMC. Infect. Dis. 6: 130. doi: 10.1186/1471-2334-6-130.

Mark, D., Leonard, C., Breen, H., Graydon, R., O'Gorman, C., and Kirk, S. 2014. Mobile phones in clinical practice: Reducing the risk of bacterial contamination. Int. J. Clin. Pract. 68(9): 1060-1064. doi: $10.1111 /$ ijcp. 12448 .

Meadow, J. F., Altrichter, A. E., and Green, J. L. 2014. Mobile phones carry the personal microbiome of their owners. Peer. J. 2: e447. doi: 10.7717 peerj. 447 .

Namias, N., Widrich, J., Martinez, O. V., and Cohn, S. M. 2000. Pathogenic bacteria on personal pagers. Am. J. Infect. Control. 28(5): 387-388. doi: $10.1067 /$ mic.2000.109183.
Pal, P., Roy, A., Moore, G., Muzslay, M., Lee, E., Alder, S., et al. 2013. Keypad mobile phones are associated with a significant increased risk of microbial contamination compared to touch screen phones. J. Infect. Prev. 14(2): 65-68. doi: 10.1177/1757177413475903.

Public Health Agency of Canada. 2013. Available at http://www. phac-aspc.gc.ca/cphorsphc-respcacsp/2013/assets/pdf/2013-eng. pdf.

Singh, D., Kaur, H., Gardner, W. G., and Treen, L. B. 2002. Bacterial contamination of hospital pagers. Infect. Control. Hosp. Epidemiol. 23(5): 274-276. doi: 10.1086/502048.

Tekerekoǧlu, M. S., Duman, Y., Serindaǧ, A., Cuğlan, S. S., Kaysadu, H., Tunc, E., et al. 2011. Do mobile phones of patients, companions and visitors carry multidrug-resistant hospital pathogens? Am. J. Infect. Control. 39(5): 379-381. doi: 10.1016/j.ajic.2010. 10.026 .

Ulger, F., Esen, S., Dilek, A., Yanik, K., Gunaydin, M., and Leblebicioglu, H. 2009. Are we aware how contaminated our mobile phones with nosocomial pathogens? Ann. Clin. Microbiol. Antimicrob. 8: 7.

Ustun, C., and Cihangiroglu, M. 2012. Health care workers' mobile phones: A potential cause of microbial cross-contamination between hospitals and community. J. Occup. Environ. Hyg. 9(9): 538-542. doi: 10.1080/15459624.2012.697419.

Vilella, A., Bayas, J.-M., Diaz, M.-T., Guinovart, C., Diez, C., Simo, D., et al. 2004. The role of mobile phones in improving vaccination rates in travelers. Prev. Med. 38(4): 503-509. doi: 10.1016/j.ypmed.2003.12.005.

White, S., Topping, A., Humphreys, P., Rout, S., and Williamson, H. 2012. The cross-contamination potential of mobile telephones. J. Res. Nurs. 17(6): 582-595. doi: 10.1177/1744987112458670.

Zoutman, D. E., Ford, B. D., Bryce, E., Gourdeau, M., Hébert, G., Henderson, E., et al. 2003. The state of infection surveillance and control in Canadian acute care hospitals. Am. J. Infect. Control. 31(5): 266-273. doi: 10.1067/mic.2003.88. 